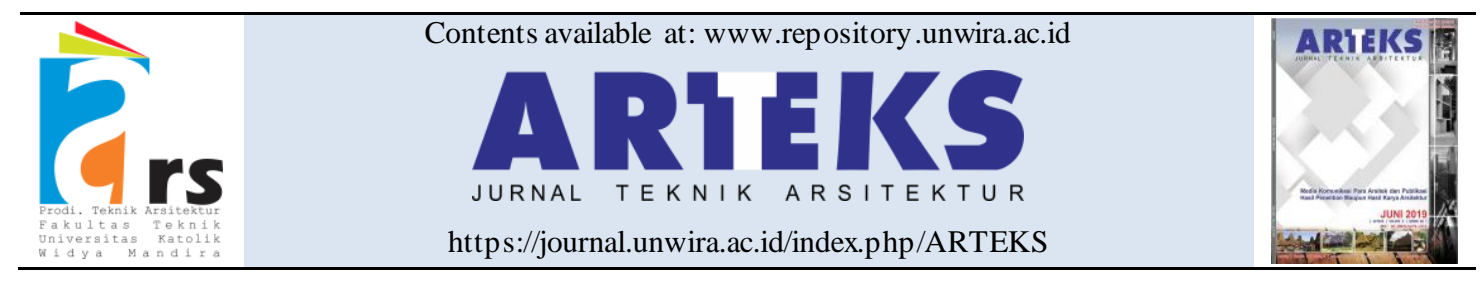

Research paper

doi: 10.30822/arteks.v6i1.626

\title{
The basic concept of Baluwarti Cirebon Palace Study case of Kasepuhan, Kanoman, and Kacirebon Palace
}

\author{
Nia Yunia Lestari, Purnama Salura* (1), Bachtiar Fauzy \\ Architecture Study Program, Faculty of Engineering, Universitas Katolik Parahyangan \\ Jl. Ciumbuleuit no. 94, Bandung, Indonesia
}

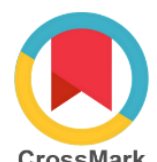

\begin{tabular}{|c|c|}
\hline ARTICLE INFO & ABSTRACT \\
\hline $\begin{array}{l}\text { Article history: } \\
\text { Received July } 14,2020 \\
\text { Received in revised form July } 21,2020 \\
\text { Accepted October } 11,2020 \\
\text { Available online April } 01,2020 \\
\end{array}$ & $\begin{array}{l}\text { Cirebon is a unique city with } 3 \text { palaces, including Kasepuhan, } \\
\text { Kanoman, Kacirebonan. The palaces are influenced by the history } \\
\text { and culture of the Baluwarti palace, which is believed to have } \\
\text { specific concepts in the arrangement and placement of building } \\
\text { masses. This study examines the concepts underlying Baluwarti in }\end{array}$ \\
\hline $\begin{array}{l}\text { *Corresponding author: Purnama Salura } \\
\text { Architecture Study Program, Faculty of } \\
\text { Engineering, Universitas Katolik } \\
\text { Parahyangan, Indonesia } \\
\text { Email: purnamasalura.ps@ unpar.ac.id } \\
\text { ORCID: https://orcid.org/0000-0002-3652- } \\
7192\end{array}$ & $\begin{array}{l}\text { the } 3 \text { Cirebon palaces. This is achieved by first studying the basis of } \\
\text { Palace's trust rules used to regulate the mass placing of the palace } \\
\text { building. Subsequently, the study uses an architectural anatomical } \\
\text { theory consisting of the building site and scope, and the property- } \\
\text { composition theory to explore the orientation and position of the } \\
\text { Palace building. The results showed that the concept underlying } \\
\text { Baluwarti in the } 3 \text { Cirebon palaces consists of Javanese and } \\
\text { Sundanese cosmologies as building orientation, the type of land on } \\
\text { which it was built, and Mahameru and the building position. This } \\
\text { research contributes to the general architecture in the uniqueness of } \\
\text { historical, cultural and local values. Also, it provides architectural } \\
\text { information regarding the concepts underlying Baluwarti in the } 3 \\
\text { Cirebon palaces. }\end{array}$ \\
\hline
\end{tabular}

\section{Introduction}

The entry of Hinduism, Buddhism and Islam in Indonesia changed various aspects of people's lives, especially in Cirebon especially. (Suwardono 2013; Forshee 2006; Frederick 2007; Drakeley 2005; Geerts 1983; Lombard 1996).

Initially, the ethnic Cirebon was always associated with Sundanese and Javanese. Later on, the community was also influenced by Hinduism, Buddhism and Islam, marked by the construction of Cirebon palaces in the 15th century, based on the Islamic religion (Ambary 1988; Lawi 2018; Suryana 2017).

The cultural influence of Hinduism, Buddhism and Islam is reflected in the physical and decorative ornaments of buildings inside the palace complex. The arrangements of Kasepuhan, Kanoman and Kacirebonan palaces is based on Baluwarti, a less familiar term within the present society (Suratman 1989). Baluwarti underlies the embodiment of the 3 palaces' construction in Cirebon.

Baluwarti terminology in the Yogyakarta and Surakarta Palace

Baluwarti has different contextual and cultural meanings in Javanese palaces, as shown in table 1 below.

Table 1. The term Baluwarti in the Yogyakarta, Surakarta and Cirebon Palaces

Palace Baluwarti Description




\begin{tabular}{|c|c|c|}
\hline $\begin{array}{l}\text { Yogyakarta } \\
(1755)\end{array}$ & Wall & $\begin{array}{l}\text { It has a common sound } \\
\text { with the word baluarte } \\
\text { from the Portuguese } \\
\text { language, which also } \\
\text { means fortress. The } \\
\text { construction period of the } \\
\text { Baluwarti wall is the same } \\
\text { as that of Tamansari, } \\
\text { designed by a Portuguese } \\
\text { architect. }\end{array}$ \\
\hline $\begin{array}{l}\text { Surakarta } \\
(1744)\end{array}$ & $\begin{array}{l}\text { Buildings } \\
\text { in the } \\
\text { palace } \\
\text { walls }\end{array}$ & $\begin{array}{l}\text { Referring to a set tlement } \\
\text { in Surakarta called } \\
\text { Baluwarti village, the only } \\
\text { village whose entire } \\
\text { population occupies the } \\
\text { land owned by the palace. }\end{array}$ \\
\hline $\begin{array}{l}\text { Cirebon } \\
\text { [Kasepuhan } \\
(1529), \\
\text { Kanoman } \\
(1678), \\
\text { Kacirebonan } \\
(1800)\end{array}$ & $\begin{array}{l}\text { The } \\
\text { building } \\
\text { pattern and } \\
\text { layout } \\
\text { inside the } \\
\text { palace } \\
\text { walls }\end{array}$ & $\begin{array}{l}\text { The construction of } \\
\text { Cirebon's palaces is } \\
\text { influenced by various } \\
\text { foreign cultures that affect } \\
\text { the value of openness. It } \\
\text { made the palace-fortress } \\
\text { only as a boundary and } \\
\text { palace buildings. } \\
\text { Baluwarti Cirebon is more } \\
\text { inclined to the palace } \\
\text { pattern and structure rules. }\end{array}$ \\
\hline
\end{tabular}

Table 1 shows a shift in values based on Baluwarti. The order of Palace establishment from the youngest is Yogyakarta, preceded by Surakarta that stood one year older. The Cirebon palaces preceded these two as the oldest, which marked the beginning of Islamic civilization on Java Island (Yoeliwati 1987). The Cirebon palaces became one of the main inspirations in the construction of Mataram Islamic palace and kingdom (Gedhe City, Plered, Kartasura, Surakarta and Yogyakarta) (Wardani et al. 2013).

There has been insufficient research on Baluwarti, especially in historical, anthropological and architectural fields. Therefore, this research explores the concepts underlying Baluwarti in the 3 Cirebon palaces.

This research is useful in various ways. First, it provides architectural information on the concepts underlying Baluwarti in the 3 Cirebon palaces. Second, it enriches the treasury of research methods by combining philological approaches with architecture. Third, the research is an academic input for the public such as city managers and policymakers, as well as conservation policies regarding the unique history, culture and local values.
Cirebon has 3 palaces, Kasepuhan, Kanoman and Kacirebonan, as shown in figure 1. Their construction started with Kasepuhan in the 1516th century, Kanoman in 1678 and, finally, Kacirebonan in 1807 (Lasmiyati 2013).

The palaces are located near the northem coastal port of Java. The Cirebon region is divided into 4 sub-cities, including SWK I (port), SWK II (city centre), in which the 3 palaces are located, SWK III (settlement and land development) and SWK IV (land and border development). Cirebon region is illustrated in figure 1 .

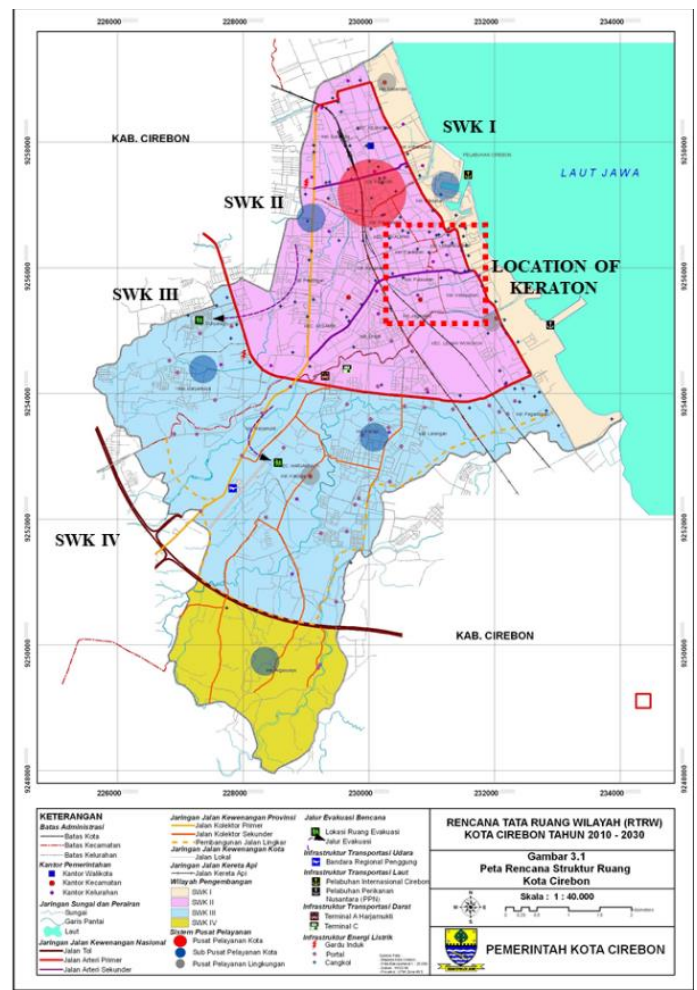

Figure 1. Location of Three Cirebon Palaces in SWK II

Source: (Pemerintah Daerah Kota Cirebon 2019)

Kasepuhan Palace, covering an area of 25 hectares, is located at Kasepuhan Street No. 43. Kanoman Palace, with an area of 6 hectares, is located on Kanoman Street No. 40. The Kacirebonan Palace covers an area of 46,500 $\mathrm{m}^{2}$, located on Pulasaren Street (figure 2). The 3 palaces serve as cultural centres in the Cirebon city (Sumardjo and Haji 1983).

\section{Method}

Location and object of study 


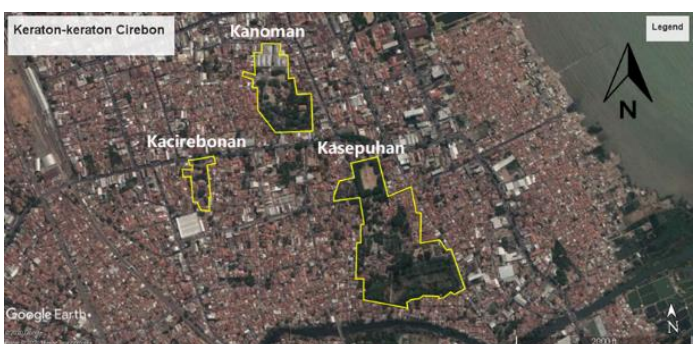

Figure 2. Location of Three Cirebon Palaces in SWK II

The site plans and Cirebon palace buildings have unique features. For instance, Kasepuhan has Dewandaru, a white tiger statue (figure 2a), Kanoman has Lemah Dawur wall with white shades (figure 2b), and Kacirebonan contains green shades on Prabayaksa (figure 2c).

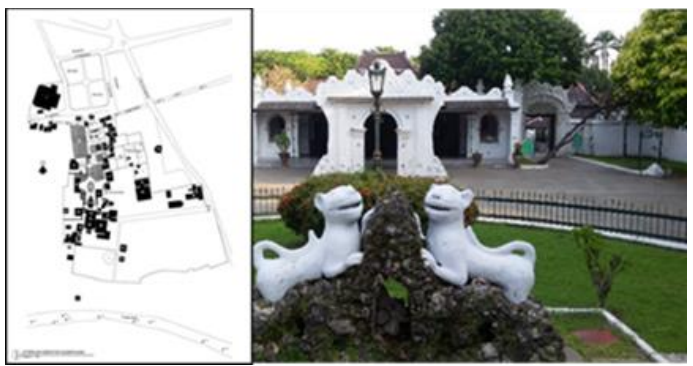

Figure 2a. Site plan and Kasepuhan Palace Source: (Syafei 2017)

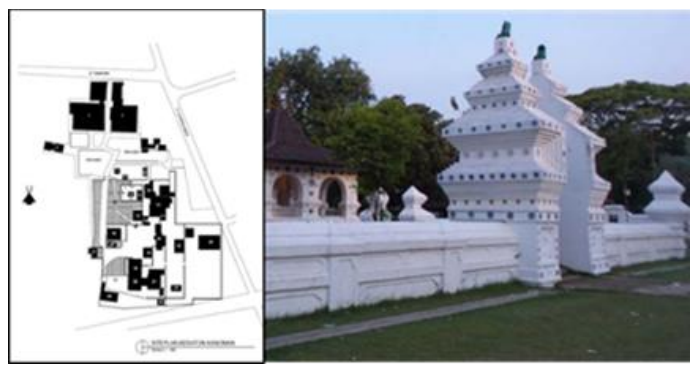

Figure 2b. Site plan and Kanoman Palace Source: (Sy afei 2017)

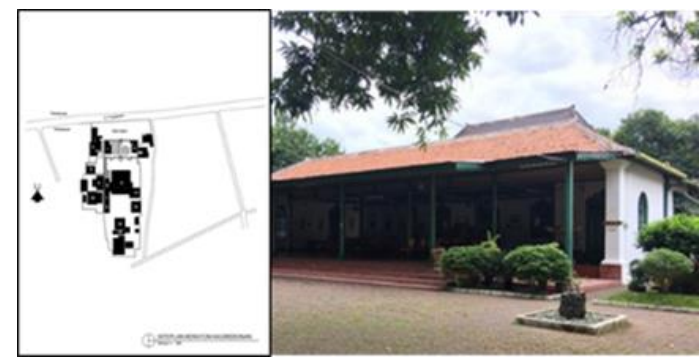

Figure 2c. Site plan and Kacirebonan Palace Source: (Sy afei 2017)

The analysis steps

The study was conducted in 3 sequential steps implemented randomly.

First, an in-depth search was conducted for the basic principles of Palace's trust rules, including Catur Gatra Tunggal, Tritangtu and Spatial layout of the Java Kingdom, based on the historical development of Cirebon palaces.

The second step involved recording and redrawing the 3 study cases, as well as classifying buildings and spaces in between them based on the property-composition concept (Salura 2018b). This step ended with a detailed analysis of each case study based on architectural anatomy (Salura 2018a).

In the third step, an analys is of each case study was interpreted. It involved interviews and the triangulation of the 3 groups' opinions. Respondents consisted of palace philologists, palace users, palace managers and palace visitors.

This research, therefore, explored the concepts underlying Baluwarti in the Cirebon palaces, based on the in-depth study.

\section{Result and discussion}

\section{The search of Palace trust rule basic}

\section{Caturgatra tunggal}

Catur gatra tunggal is the principle of palace trust rule basis originating from the Javanese language, catur and gatra. Catur means four, while gatra is pillar or building. Therefore, Catur gatra tunggal is the structure of the palace and space, with 4 pillars of life, including economic, socio-cultural, political and religious. This concept is reflected in markets, squares, palaces and mosques, as the general elements in palace construction (Susanti, S., and W. 2018).

The 3 Cirebon palaces have all the elements necessary for the construction of a palace. However, the compatibility of these elements 
with those described by catur gatra tunggal in terms of embodiment and position is described in table 2 below.

Table 2. Analy sis for catur gatra tunggal of 3 Cirebon Palaces

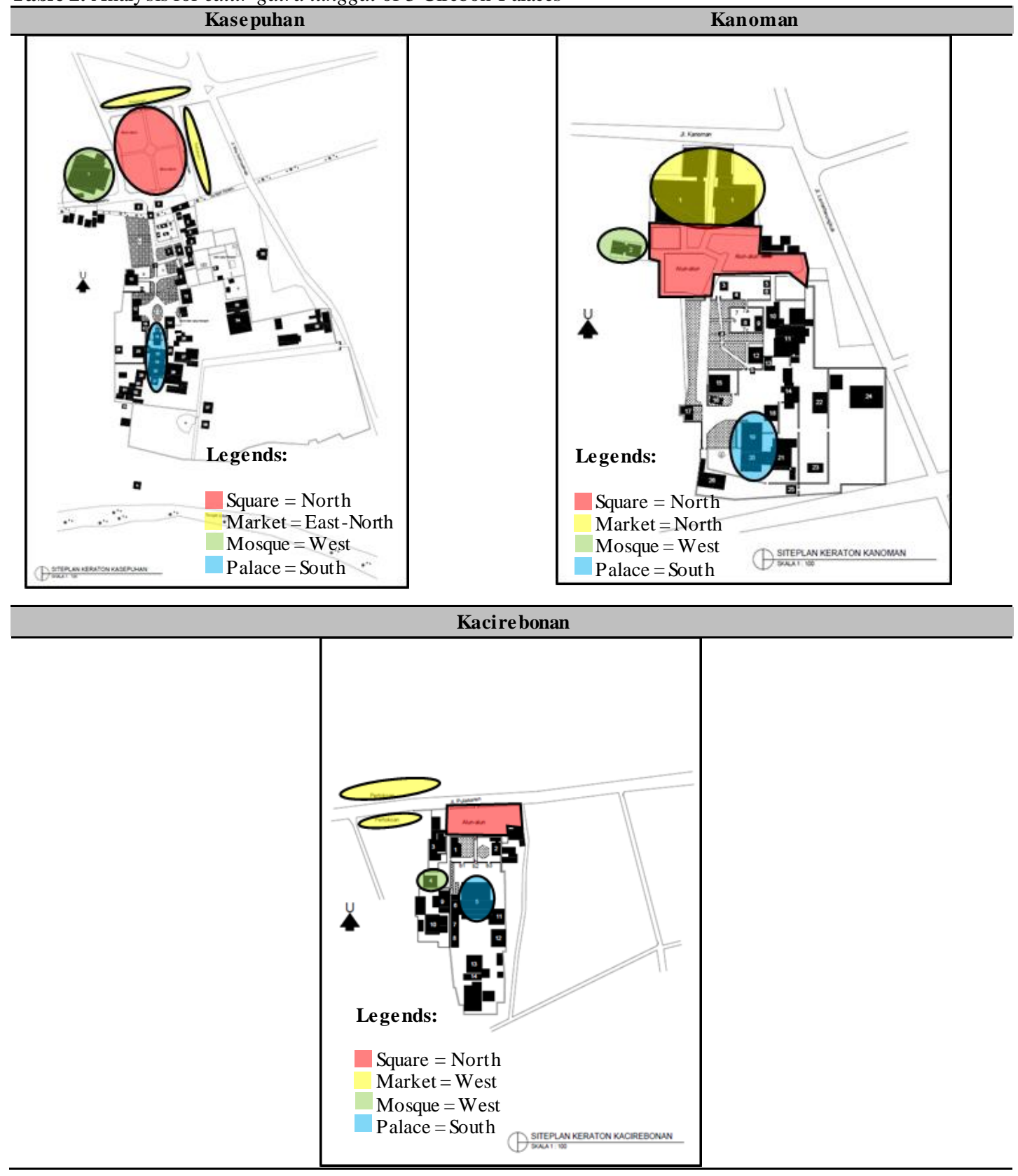

From table 2, the Cirebon palaces are located in different positions on caturgatra tunggal. The market area in Kasepuhan extends from east to north. In Kanoman, the market is in the north, covering the square. In Kacirebonan, the market is in the western area. These different positions are influenced by time development.

From the above analysis, more changes occur in the market. The other 3 elements, including the square, Mosque and Palace, are in line with catur gatra tunggal to the present. 


\section{The tritangtu concept}

Tritangtu is 3 principles of ancient Sundanese teachings, including the individual Sundanese philosophical perspective, the nature of the environment and God (Sumardjo and Haji 1983). The principles are based on Mundinglaya Dikusumah and Eyang Reusi Handela's statement that there are 3 worlds interpreted as the bottom world (the people), the middle world (teachings \& law), and the upperworld (government).

The first world (people), consisting of the square, market and its surroundings, is occupied by the community. The second world (teachings $\&$ religion) relates to religious rules and elements such as mosques. The third world (government) is a palace. The analysis is shown in table 3 below.

Table 3. Analy sis for the division of 3 worlds in Cirebon Palaces

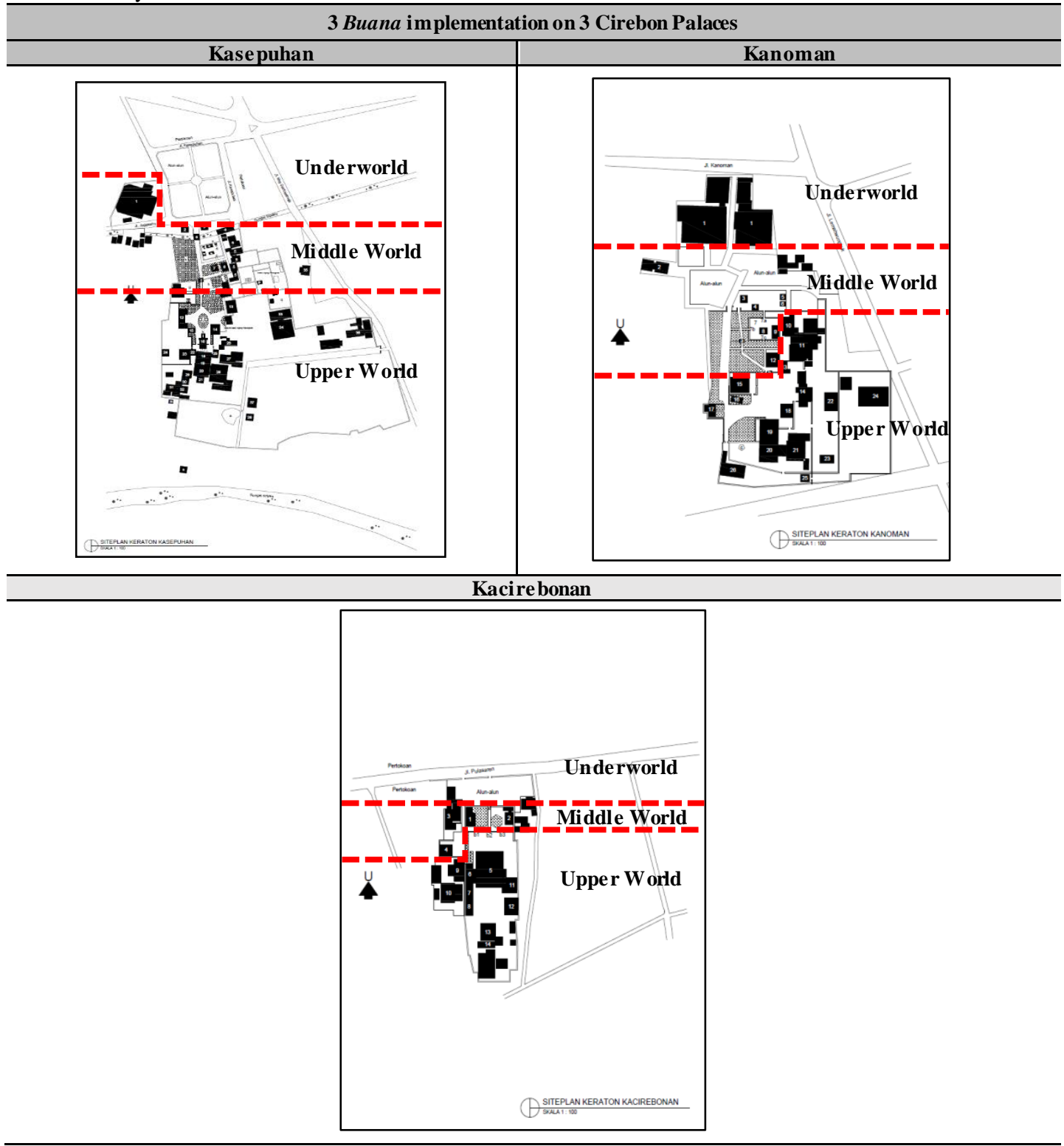

In table 3 , the bottom world relates to the people, whose liaison with the government is reflected by the square.
The middle world relates to religious and legal values, indicated by religious symbols. For example, in Kasepuhan, the value of Islam was shown by Siti Inggil, while in Kanoman, it was 
symbolized by Lemah Dawur. In Kacirebonan, the Is lamic value was shown by the green nuances that dominated Prabyaksa. The upper world relates to politics and authority, indicated by the Palace (Prabayaksa) as a cosmic centre and symbol of royal power (Agustina 2015).

The Cirebon palaces have 3 distinct territorial divisions and locations, with a strong cosmological element.

3. History of the Palace development in Cirebon

Dalem Agung Pakungwati was the first government centre of the Cirebon sultanate, established by Walasungsang/Cakrabuwana as the successor and symbol of the Pajajaran kingdom (Bochari 2001). The area lies east of the Kasepuhan palace complex. The development of the Pakungwati era was associated with a strong Hindu element. It became part of the Kasepuhan complex with an area of approximately 25 hectares.

A few years later, the Kanoman palace was founded by Prince Kertawijaya, titled as Sultan Anom I. At that time, the Cirebon sultanate had 2 governments, Kasepuhan and Kanoman. Subsequently, a conflict arose within the royal family, causing the son of Sultan Anom IV to seek separation. With the intervention of the Dutch, Kanoman finally split, giving rise to the Kacirebonan Palace.

\section{Java Kingdom spatial layout}

The Java Kingdom spatial layout consists of 5 layers of hierarchy (Santoso 2008). The position of the layer structure was further transformed with the entry of Islam (Agustina, Hindersah, and Asiyawati 2017). It is illustrated in figure 3 below.

Dalem is the centre of Mount Mahameru, the highest mountain in the Java land considered to be sacred. Mahameru is also the cosmic centre of government. The negara (country) layer was assimilated into the negara agung (great country) that functions as a parentah jero (internal government system).

The mancanegara (overseas) layer functions as a parentah jaba (external government system). Furthermore, there is a new layer in the spatial layout of the Is lamic Kingdom, the beach, serving as the entry port for the Islamic culture. Finally, the tanah seberang (opposite land) forms yet another kingdom.

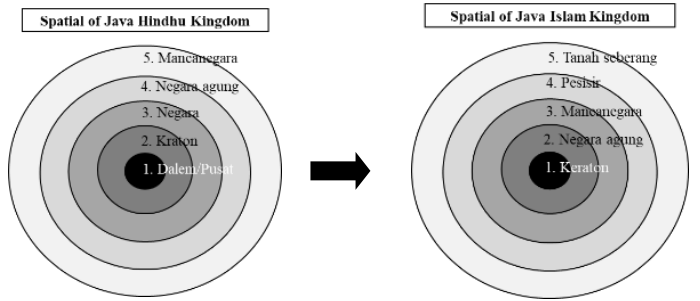

Figure 3. Spatial layout of Hindu and Islamic Java Kingdom

Source: (Santoso 2008) (left) and (Agustina, Hindersah, and Asiy awati 2017) (right)

Initially, the structural layer of the Hindu Java Kingdom was only used in analyzing the Cirebon Palaces. However, it was changed following the entry and development of Is lamic culture. Tables 4, 5 and 6 below illustrate the details of the Java Kingdom spatial layout on each of the 3 Cirebon Palaces.

Table 4. Analy sis of Java Kingdom spatial lay out in Kasepuhan

\begin{tabular}{|c|c|}
\hline Place & Description \\
\hline $\begin{array}{l}\text { Allied kingdom, ot hers } \\
\text { kingdom }\end{array}$ & \multirow{4}{*}{$\begin{array}{l}\text { The layout of the Islamic } \\
\text { Javanese kingdom is perfectly } \\
\text { implemented in the Kasepuhan } \\
\text { palace, the placement \& position } \\
\text { of the building in accordance } \\
\text { with function and level of } \\
\text { position. }\end{array}$} \\
\hline Port & \\
\hline $\begin{array}{l}\text { Square, the great } \\
\text { mosque, pancaniti, } \\
\text { pancaratna, Siti Inggil, } \\
\text { Wanowati, Langgar } \\
\text { Agung }\end{array}$ & \\
\hline $\begin{array}{l}\text { Lunjuk, Jinem } \\
\text { pangrawit, Paseban }\end{array}$ & \\
\hline
\end{tabular}




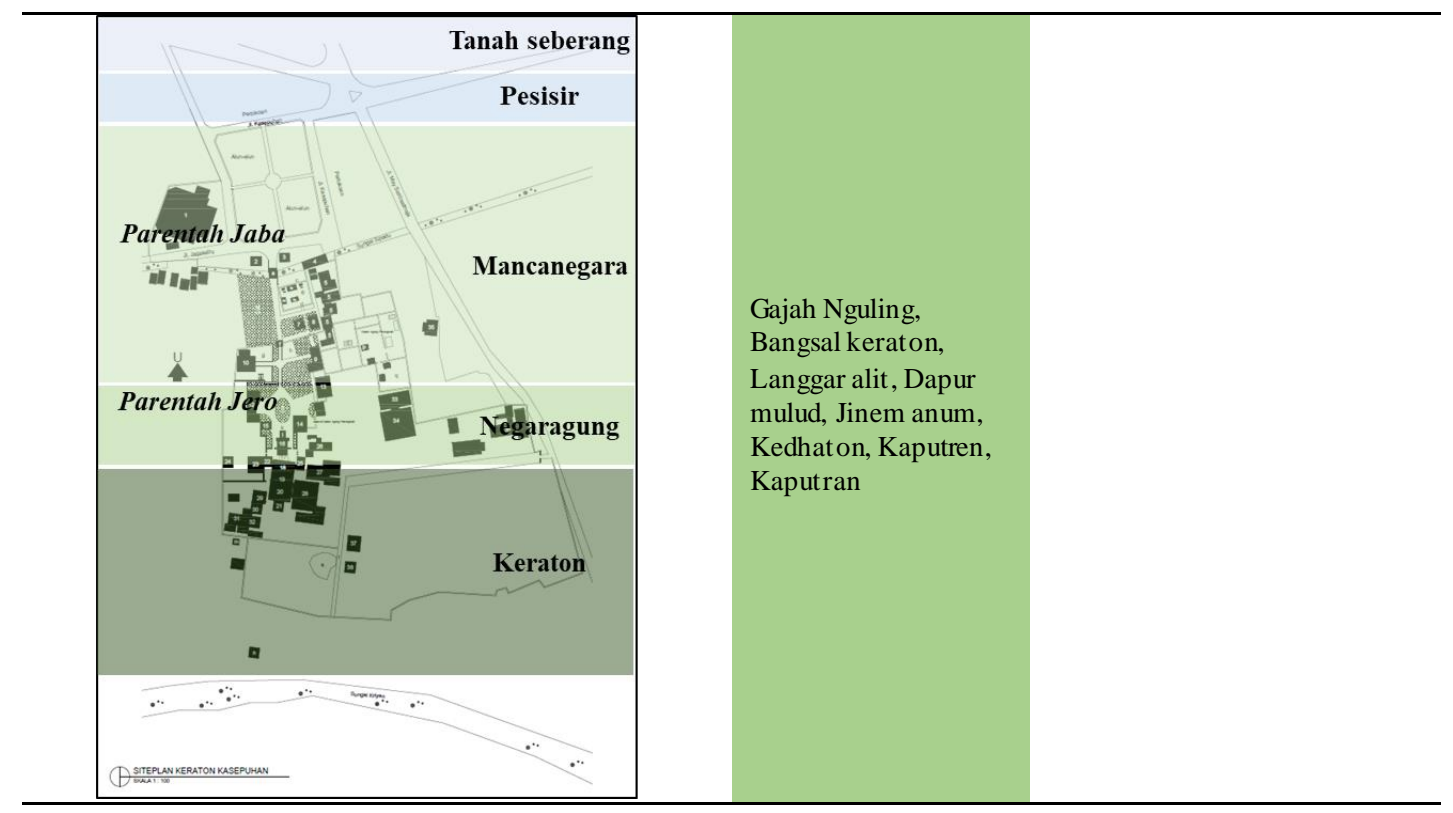

Table 5. Analy sis of Java Kingdom spatial lay out in Kanoman

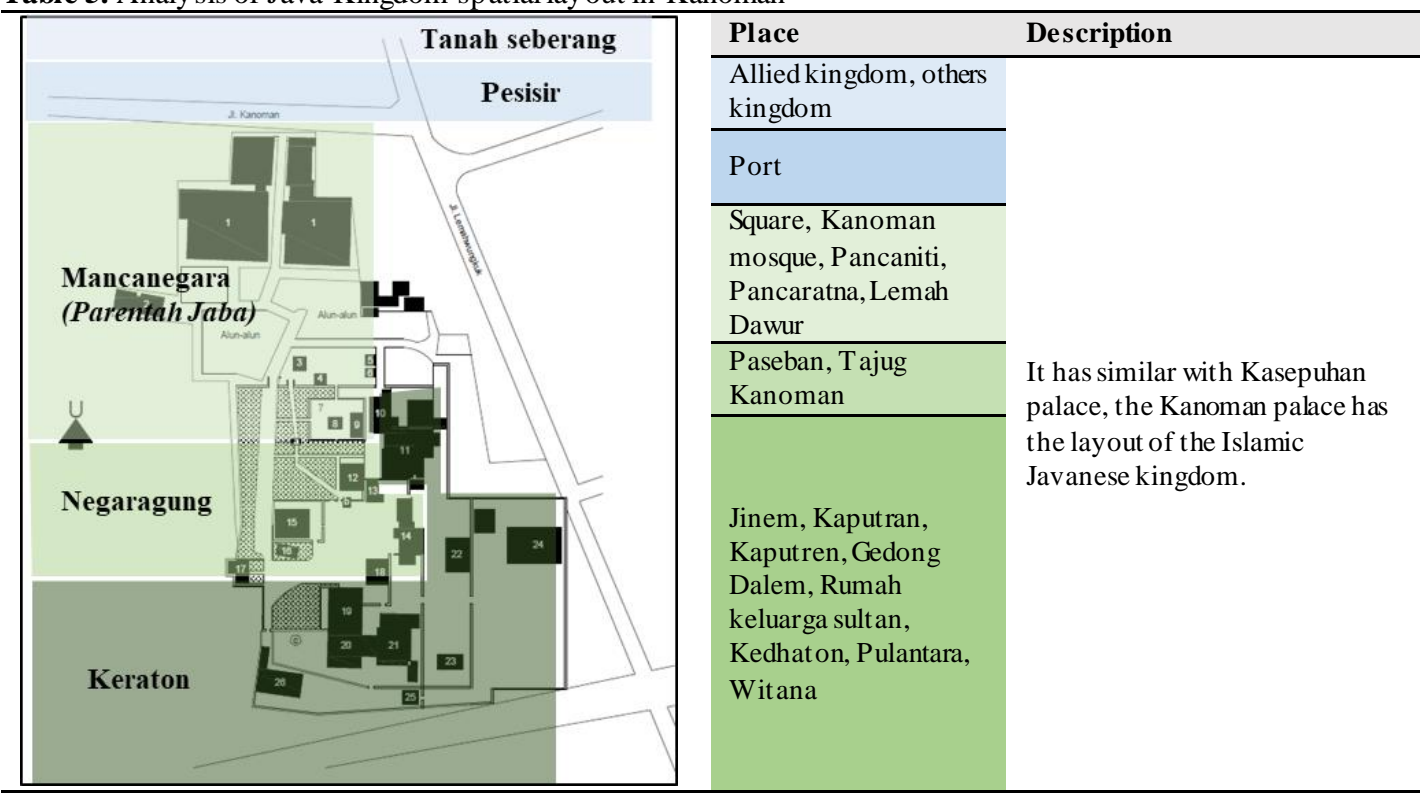

Table 6. Analy sis of Java Kingdom spatial lay out in Kacirebonan

\begin{tabular}{ll} 
Place & Description \\
\hline $\begin{array}{l}\text { Allied kingdom, } \\
\text { others kingdom }\end{array}$ & $\begin{array}{l}\text { It has similar with two } \\
\text { Cirebon palaces, the } \\
\text { Kacirebonan palace has the } \\
\text { layout of the Islamic } \\
\text { Javanese kingdom, only the } \\
\text { buildings become fewer but }\end{array}$ \\
\cline { 1 - 2 } Square &
\end{tabular}




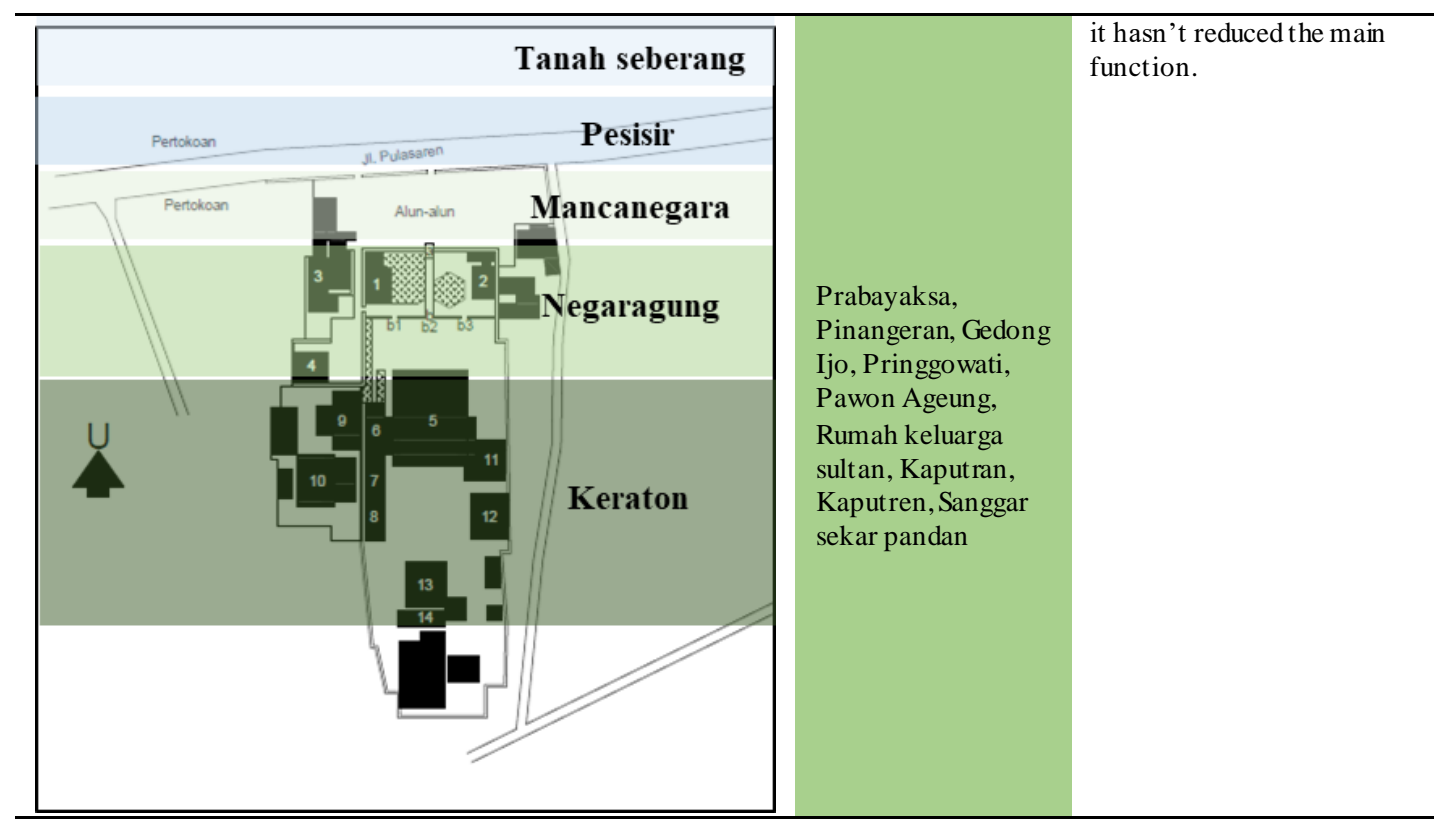

The Cirebon palaces reflect the Islamic Java Kingdom spatial layout. They are located close to the Muara Jati port, which is the entrance to Cirebon from the north coast.

Cirebon Palaces have similar layouts and building positions. The fractional palaces are similar, which also extends to the rules, location and functions of the buildings. This indicates an effective implementation of the spatial layout of the Islamic Java Kingdom, with the coast layer being shared by all the 3 palaces.

\section{Elaboration of architectural anatomy theories} on site and building scopes

1. Site scope (palace location and case study) Cirebon is located on the port area, north coast of Java. It lies between $6^{\circ} \quad 41^{\prime} \quad \mathrm{S} 108^{\circ} \quad 33^{\prime} \quad \mathrm{E}$ North coast of Java Island, the eastern part of West Java, extending $8 \mathrm{~km}$ from West to East, and $11 \mathrm{~km}$ from North to South. The area rises 5 meters above the sea level (including lowlands), as illustrated in figure 4 below.

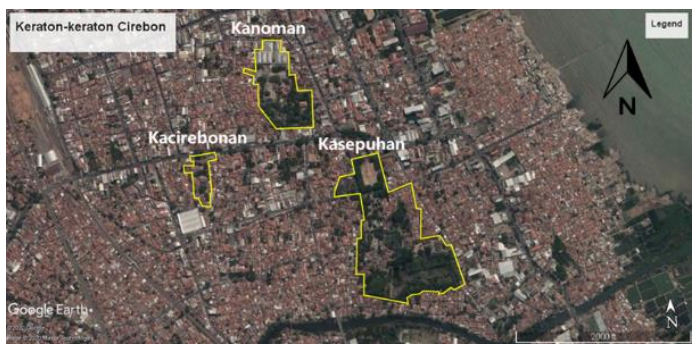

Figure 4. Site of 3 Cirebon Palaces

2. Building scope (general and specific palace building)

The palace buildings include the plaza, market, mosque and royal residence, as depicted in tables 7 and 8 .

Table 7. General building of 3 Cirebon Palaces (building analy sis)

\begin{tabular}{lcccc}
\hline \multirow{2}{*}{ Palace } & \multicolumn{5}{c}{ General palace elements/buildings } \\
\cline { 2 - 5 } & Square & Market & Mosque & Palace \\
\hline Kasepuhan & $\mathrm{V}$ & $\mathrm{V}$ & $\mathrm{V}$ & $\mathrm{V}$ \\
\hline Kacnoman & $\mathrm{V}$ & $\mathrm{V}$ & $\mathrm{V}$ & $\mathrm{V}$ \\
\hline Kacirebonan & $\mathrm{V}$ & $\mathrm{V}$ & $\mathrm{V}$ & $\mathrm{V}$ \\
\hline
\end{tabular}


Table 8. Cirebon Palaces specific buildings (building location analy sis)

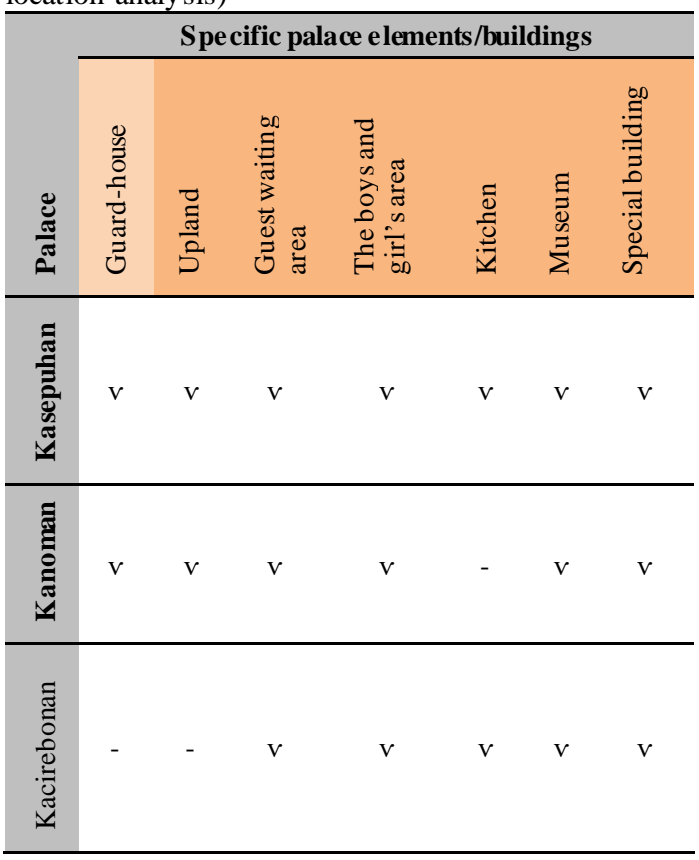

From tables 7 and 8 , the locations of the Cirebon palaces are divided into the outside and inside complex, marked as green and red. The green colour indicates that the palace building is outside the complex and facing to the north, while red implies that the building is inside the palace complex, oriented to the south.

The main palace buildings are located outside the complex except the King's residence. However, all specific buildings are inside the complex, except the Guard House (Pancaniti \& Pancaratna).

Specific palace buildings have several supporting buildings that are different from each other, based on the different needs of each palace. For instance, there is a guardhouse only in Kasepuhan and Kanoman and not Kacirebonan.
3. Site scope (palace properties and compositions)

In the site scope, the 3 palaces are equally facing ropert (figure 5)

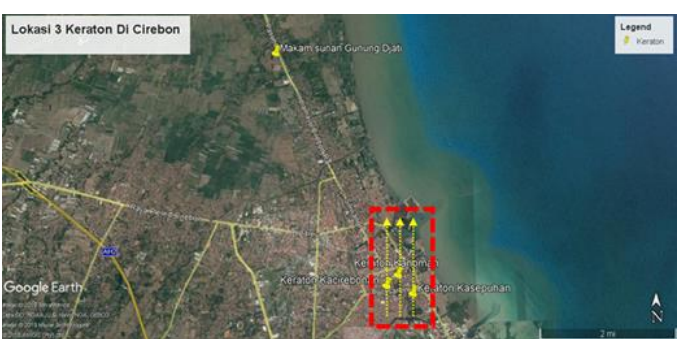

Figure 5. The orientation of 3 palaces facing report

All the palaces are located in Cirebon, which is a lowland ( \pm 5 meters above sea level), facing North. The site arrangement forms a linear pattem with a North-South axis (figure 6).

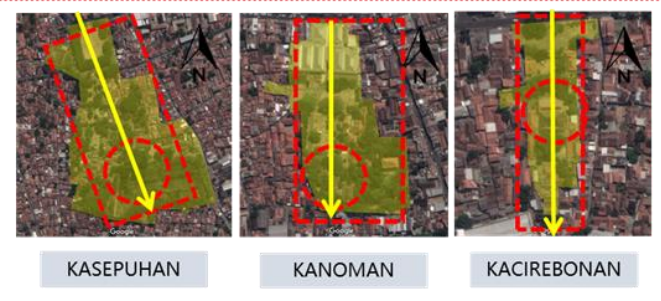

Figure 6. The pattern of 3 palaces site

4. Building scope (palace properties and compositions)

Palace property such as the square, market and worship places are outside, while the king's residence is inside the palace complex. However, all specific buildings are located in the palace complex, spreading from I to IV yards. Based on the functionality, the general property lies in the I yard outside the complex. The II, III to IV yards have a higher sacred function. The analys is retrieved from the site plan is illustrated in table 9. 
Table 9. Property analy sis and composition in site scope at 3 palaces (y ard distribution analy sis)

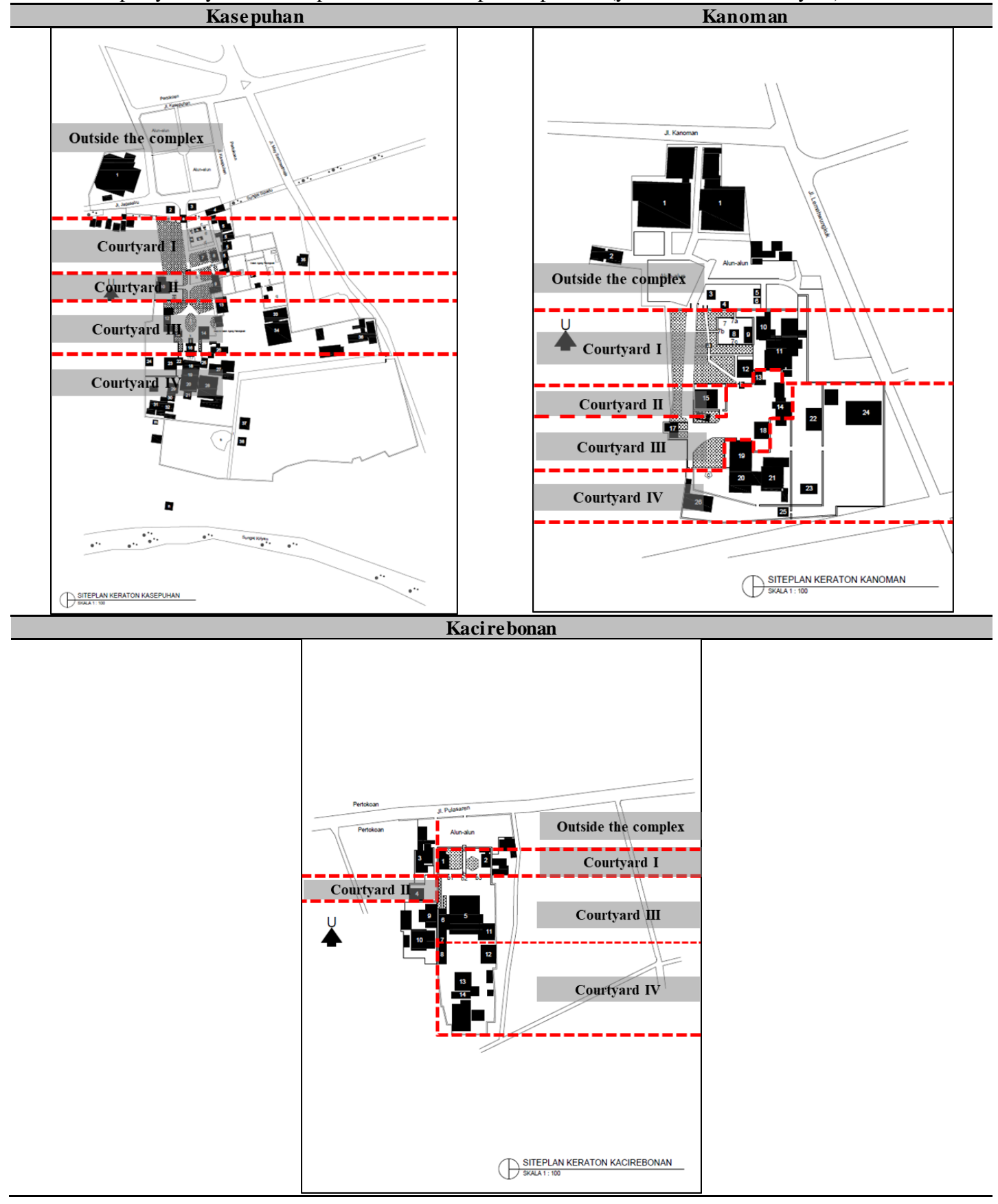

Property elaboration and palace building composition in triangulation method (Respondents: philologists, users, and visitors)

1. Analysis of respondent's perspectives on Cirebon topographic areas

Cirebon region lies to the north-east of Ciremai, facing the ocean. The 3 palaces are located on the golden Bokor site, the primbon language used by the Cirebon people to describe the construction and settlement soil. In the Warugan Lemah manuscripts (ancient Sundanese manuscripts describing various terms of topographical conditions), the gold Bokor is included in the Talaga Hangsa (land leaning to the north), Purba Tapa (land leaning to the east) and Sunara Dadaya (flat land or harbor). 
The Cirebon palaces face the north coast of Java, away from Mount Ciremai. This region is subdivided into the upper (mountains), middle (settlements and palace) and bottom (sea) world. This concept is similar to the Tritangtu 3-world concept.

2. Analysis of respondent's perspectives on the three Cirebon Palaces

In this analysis, philologists discussed the orientation, concepts and functions of the 3 Cirebon palaces. The users shared information on yard division, orientation, building type and function, while the visitors distinguished building functions into 4 zonings.

The philologists described the Kasepuhan palace as a duplication of 3 Hindu shrines, including Indraprahasata (palace), Indrakila, indrakila hill (artificial hill behind Kasepuhan) and the river Ganges, the kriyan river (the southern border of Kasepuhan). All the respondents had similar views regarding Kanoman and Kacirebonan. The most important buildings in terms of function and position were private and located on the deeper yards of the palace (p. III / IV).

Based on the respondents' analys is, the palace buildings have specific functions, yard divisions and zoning based on hierarchy. For example, the guardhouse is profane and public, located on yard I. Similarly, the public and semi-public guest rooms are sacred, and therefore located on Yard III and IV. However, some building functions may change according to palace needs and customary events to be held. This also applies to kitchens, museums and specific buildings in every Cirebon palace.

From the respondents' interpretation, the general and specific buildings are arranged according to their roles and needs in a hierarchical order. More sacred building are placed inside the palace complex, while the rather profane ones are placed on the outside. Furthermore, the most sacred and private buildings are usually located in yard IV. The results are summarized in table 10 below.

Table 10. Analy sis result

\begin{tabular}{|c|c|c|}
\hline \multirow{3}{*}{$\begin{array}{l}\text { The foundation of the } \\
\text { rules royals belief }\end{array}$} & Anatomy of architecture theory & \multirow{3}{*}{ Analysis result } \\
\hline & Building scope & \\
\hline & Property and composition study & \\
\hline Caturgatra tunggal & $\begin{array}{l}\text { The Courtyard division \& building orientation are part of } \\
\text { the Hindu Javanese belief }\end{array}$ & Javanese Cosmology \\
\hline \multirow[b]{2}{*}{ Tritangtu } & $\begin{array}{l}\text { The Division of } 3 \text { regions, the upper world (mountains), the } \\
\text { middle (settlements), the lower (seas). The concept of } 3 \\
\text { worlds in ancient Sundanese poetry }\end{array}$ & \multirow[b]{2}{*}{ Sundanese Cosmology } \\
\hline & $\begin{array}{l}\text { 'Bokor emas' (leading to northeast). In the manuscript } \\
\text { Warugan Lemah it refers to Talaga Hangsa, Purba T apa, } \\
\text { Sunara Dadaya } \\
\text { Ancient Sundanese Manuscript }\end{array}$ & \\
\hline History & $\begin{array}{l}\text { The majority of development period in the Cirebon palaces } \\
\text { was during in the period when Hindu elements dominated }\end{array}$ & Hindu Culture \\
\hline \multirow[b]{2}{*}{ Spatial of Royal Javanese } & $\begin{array}{l}\text { The placement of the buildings Cirebon palaces is largely } \\
\text { accordance with the layout of the Hindu palace }\end{array}$ & \multirow[b]{2}{*}{ Mahameru Concept } \\
\hline & $\begin{array}{l}\text { The division of the layout palace is a duplication of the } \\
\text { Mahameru mountain hierarchy }\end{array}$ & \\
\hline
\end{tabular}

\section{Conclusion}

Baluwarti is the entire building pattern and layout inside the walls in the Cirebon Palaces.

The underlying Baluwarti concepts in the 3 Cirebon Palaces include the Javanese cosmology, applied as the Cirebon Palace building orientation, the Sundanese cosmology, applied as the land type choice for the establishment of Cirebon Palaces, and the Mahameru concept, applied as the regulation of buildings position outside and inside the Cirebon Palace complex.

The Javanese and Sundanese cosmologies, as well as the Mahameru concept, are a reference input for city policy managers and conservation policies when initiating improvements or changes to the 3 palaces.

The research is useful in analyzing other similar cases, serving as a starting point for other more detailed and varied studies regarding the Cirebon and other palaces in Indonesia. 


\section{References}

Agustina, Ina Helena. 2015. 'Pergeseran Makna Ruang Simbolik Ke Ruang Pragmatis Kawasan Keraton Kasepuhan'. Univesitas Gadjah Mada.

Agustina, Ina Helena, Hilwati Hindersah, and Yulia Asiyawati. 2017. 'Identifikasi Simbo1Simbol Heritage Keraton Kasepuhan'. ETHOS (Jurnal Penelitian Dan Pengabdian) $5 \quad$ (2): 167. https://doi.org/10.29313/ethos.v5i2.2346.

Ambary, H. 1988. Peranan Cirebon Sebagai Pusat Pengembangan Dan Penyebaran Islam. Jakarta: Departemen Pendidikan dan Kebudayaan.

Bochari, M. Sanggupri. 2001. Sejarah Kerajaan Tradisional Cirebon. Jakarta.

Drakeley, Steven. 2005. The History of Indonesia. Westport, Conn.: Greenwood Press.

Forshee, Jill. 2006. Culture and Costumes of Indonesia. W setport: Greenwood Press.

Frederick, William H. 2007. 'The History of Indonesia . By Steven Drakeley'. The Historian $69 \quad$ (3): $\quad$ 571-72. https://doi.org/10.1111/j.15406563.2007.00189_45.x.

Geerts, Clifford. 1983. Abangan, Santri, Priyayi Dalam Masyarakat Jawa. Jakarta: Pustaka Jaya.

Lasmiyati. 2013. 'Keraton Kanoman Di Cirebon (Sejarah Dan Perkembangannya)'. Patanjala: Jurnal Penelitian Sejarah Dan Budaya 5 (1): 128. https://doi.org/10.30959/patanjala.v5i1.184.

Lawi, Gloria Fransisca Katharina. 2018. 'MenyusuriSejarah Is lam Cirebon Di Keraton Kanoman Dan Keraton Kasepuhan'. Bisnis.Com. 2018. https://traveling.bisnis .com/read/20181023/2 24/852439/menyusuri-s ejarah-is lam-cirebondi-keraton-kanoman-dan-keraton-kasepuhan.

Lombard, Denys. 1996. Nusa Jawa: Silang Budaya II: Jaringan Asia. Jakarta: PT. Gramedia Pustaka Utama.

Pemerintah Daerah Kota Cirebon. 2019. 'Geografis Kota Cirebon'. Cirebonkota.Go.Id. 2019. https://www.cirebonkota.go.id/tentangcirebon/geografis/\#.

Salura, Purnama. 2018a. 'Anatomy of Architecture Based on the Creation of Space for Activity'. International Journal of Engineering and Technology(UAE) 7 (2.14): 205-7.

https://doi.org/10.14419/ijet.v7i2.12.14675.

_. 2018b. 'The Philosophy of Architectural

Ordering Principles'. International Journal of Engineering and Technology (UAE) 7 (2.9):

52-55.

https://doi.org/10.14419/ijet.v7i2.9.13346.

Santoso, Jo. 2008. Arsitektur-Kota Jawa: Kosmos, Kultur \& Kuasa. Jakarta: Centropolis, Magister Teknik Perencanaan, Universitas Tarumanegara.

Sumardjo, Unang, and Raden Haji. 1983. Meninjau Sepintas Panggung Sejarah Pemerintahan Kerajaan Cirebon 1479-1809. Bandung: Tarsito.

Suratman, Darsiti. 1989. Kehidupan Dunia Keraton Surakarta 1830-1939. Yogyakarta: Yayasan Penerbitan Tamansiswa.

Suryana, Yanyan. 2017. 'Hindu-Budha-Islam Cultural Acculturation in Indonesian National History'. JURNAL PENDIDIKAN ILMU $\begin{array}{llll}\text { SOSIAL } & 26 & \text { (1): } & \end{array}$ https://doi.org/10.17509/jpis.v26i1.6925.

Susanti, Wiwik Dwi, M. Pratono S., and Sri Suryani Y. W. 2018. 'The Study of Public Space From The Sociofugal and Sociopetal Aspect (Case Study: Faculty of Architecture and Design, UPN)'. In International Seminar of Research Month 2018: Science and Technology for People Empowerment, 75-81. Jawa Timur. http://nstproceeding.com/index.php/nusciente ch/article/view/86/84.

Suwardono. 2013. Sejarah Indonesia Masa Hindhu Budha. Yogyakarta: Ombak.

Syafei, Faqih Rohman. 2017. 'Melongok Potensi Wisata Keraton Kasepuhan Cirebon'. AyoCirebon.Com. 2017. https://www.ayocirebon.com/read/2017/08/1 8/429/melongok-potensi-wis ata-keratonkasepuhan-cirebon.

Wardani, Laksmi Kusuma, R. M. Soedarsono, Timbul Haryono, and Djoko Suryo. 2013. 'City Heritage Of Mataram Islamic Kingdom In Indonesia (Case Study Of Yogyakarta Palace)'. The International Journal of Social Sciences 9 (1): 104-18.

Yoeliwati, S. 1987. Masuk dan Berkembangnya Agama Islam di Daerah Banten dan Sekitarnya. Bandung: Universits Padjajaran. 